\title{
ANALISA PERFORMANSI TANGGAPAN TEGANGAN SISTEM EKSITASI GENERATOR TERHADAP PERUBAHAN PARAMETER
}

\author{
Heru Dibyo Laksono ${ }^{1}$, Adry Febrianda ${ }^{2}$ \\ ${ }^{1}$ Jurusan Teknik Elektro Universitas Andalas \\ ${ }^{2}$ Mahasiswa Teknik Elektro Universitas Andalas \\ e-mail : heru_dl@ft.unand.ac.id
}

\begin{abstract}
Abstrak-Jurnal ini membahas tentang analisa performansi tanggapan tegangan sistem eksitasi generator terhadap perubahan parameter. Perubahan parameter pada sistem eksitasi generator akan mempengaruhi performansi tanggapan tegangan sistem eksitasi generator baik performansi dalam domain waktu maupun performansi dalam domain frekuensi. Dengan menggunakan bantuan perangkat lunak Matlab dilakukan analisa performansi tanggapan tegangan sistem eksitais generator dalam domain waktu dan domain frekuensi. Untuk performansi dalam domain waktu terdiri dari analisa kesalahan dan analisa peralihan sedangkan untuk performansi dalam domain frekuensi terdiri dari performansi lingkar terbuka dan performansi lingkar tertutup. Untuk perubahan parameter yang yang dilakukan adalah perubahan konstanta penguatan amplifier, perubahan konstanta waktu amplifier, perubahan konstanta penguatan generator dan perubahan konstanta waktu generator. Hasil analisa menunjukan bahwa performansi tanggapan tegangan sistem eksitasi generator dalam domain waktu dan domain frekuensi sangat peka terhadap perubahan parameter terutama untuk perubahan konstanta penguatan amplifier, perubahan konstanta waktu amplifier, perubahan konstanta penguatan generator dan perubahan konstanta waktu generator. Adapun perubahan konstanta penguatan amplifier berkisar antara $10.0000 \mathrm{~s} / \mathrm{d} 45.0000$, perubahan konstanta waktu amplifier berkisar antara $0.0200 \mathrm{~s} / \mathrm{d} 0.1000$, perubahan konstanta penguatan generator berkisar antara $0.7000 \mathrm{~s} / \mathrm{d}$ 1.0000 dan perubahan konstanta waktu generator berkisar antara $1.0000 \mathrm{~s} / \mathrm{d} 2.0000$.
\end{abstract}

Kata kunci : sistem eksitasi, performansi, domain waktu, domain frekuensi, parameter.

\begin{abstract}
This journal discusses about performance analysis of generator excitation system voltage response towards parameters changes. Changes in the parameters of the generator excitation system will affect the response voltage generator excitation system performance, in both time domain and frequency domain performances. The performance analysis of the generator excitation system voltage response in both time domain and frequency domain, conduct with the help of Matlab software. For performance in the time domain is consists of error analysis and transient analysis, while for performance in the frequency domain is consists of the open-loop performance and closed-loop performance. The parameters that to be changed are the amplifier gain constant, amplifier time constant, generator gain constant, and generator time constant. The analysis result shows that the performance of the generator excitation system voltage response in both time domain and frequency domain performances is very sensitive towards the changes in the parameters, especially for the changes of amplifier gain constant, the changes of amplifier time constant, the changes of generator gain constant, and the changes of generator time constant. The changes in amplifier gain constant is about between 10.0000 to 45.0000 , while the changes in amplifier time constant is about between $0.0200 \mathrm{~s} / \mathrm{d} 0.1000$, and the changes in generator gain constant is about between $0.7000 \mathrm{~s} / \mathrm{d} 1.0000$, while the changes in generator time constant is about between $1.0000 \mathrm{~s} / \mathrm{d} 2.0000$.
\end{abstract}

Keywords: Excitation System, Performance, Time Domain, Frequency Domain, Parameters.

\section{PENDAHULUAN}

Perubahan parameter pada sistem eksitasi generator akan mempengaruhi performansi tanggapan tegangan sistem eksitasi generator baik performansi dalam domain waktu maupun performansi dalam domain frekuensi. Sistem eksitasi adalah suatu peralatan yang berguna untuk menjaga performansi tegangan dan daya reaktif generator agar tetap pada nilai operasi yang diinginkan. Pertambahan daya reaktif pada sisi beban akan menyebabkan penurunan magnitude tegangan terminal. Penurunan tegangan terminal ini kemudian akan disensor oleh suatu potensial transformator. Selanjutnya tegangan terminal akan disearahkan dan dibandingkan dengan suatu titik nilai acuan [1],[2]. Pengatur sinyal kesalahan penguat akan 
mengatur tegangan eksitasi sehingga tegangan eksitasi generator akan meningkat. Jika tegangan eksitasi meningkat maka daya tegangan yang dibangkitkan oleh generator akan meningkat pula. Sistem eksitasi generator merupakan elemen penting untuk membentuk profil tegangan terminal generator yang stabil. Sistem pengoperasian unit eksitasi generator ini berfungsi untuk menjaga agar tegangan generator tetap konstan dengan kata lain generator akan tetap mengeluarkan tegangan yang selalu stabil tidak terpengaruh pada perubahan beban yang selalu berubah-ubah, dikarenakan beban sangat mempengaruhi tegangan keluaran generator (3).

Beberapa penelitian yang sudah dilakukan diantaranya [1], pada jurnal ini dibahas pemodelan dan analisa sistem eksitasi generator. Model sistem eksitasi yang dibahas meliputi sistem eksitasi generator tipe arus searah, model sistem eksitasi generator tipe arus searah dengan Rate Output Feedback, model sistem eksitasi generator tipe arus searah dengan Transient Gain Reduction dan model sistem eksitasi generator tipe statik. Hasil analisa memperlihatkan bahwa sistem eksitasi generator tipe arus searah dengan Rate Output Feedback memiliki performansi, kestabilan dan kekokohan yang lebih baik dibandingkan dengan sistem eksitasi generator tipe arus searah, sistem eksitasi generator tipe arus searah dengan Transient Gain Reduction dan sistem eksitasi generator tipe statik. [4], pembahasan pada jurnal ini meliputi perancangan dan analisa kendali sistem eksitasi generator tipe arus searah dengan PIDTool model paralel. Hasil analisa memperlihatkan bahwa sistem kendali eksitasi generator tipe arus searah dengan pengendali Proporsional Diferensial dengan Filter Orde Pertama Pada Bagian Diferensial (PDF) memenuhi kriteria perancangan yang diinginkan. [5], membahas evaluasi pola tingkah laku tegangan sistem eksitasi generator dengan metoda penempatan kutub menggunakan algoritma Bass - Gura. Adapun informasi yang diperoleh, bahwa pola tingkah laku tegangan sistem eksitasi generator dengan metoda penempatan kutub menunjukkan performansi yang lebih baik dibandingkan performansi pola tingkah laku tegangan sistem eksitasi tanpa metoda penempatan kutub. [6], membahas evaluasi kestabilan dan kekokohan tanggapan tegangan sistem eksitasi generator dengan metoda penempatan kutub menggunakan algoritma Ackerman dan diperoleh informasi bahwa kestabilan dan kekokohan tanggapan tegangan sistem eksitasi generator menunjukkan performansi kestabilan dan kekokohan yang lebih baik dibandingkan performansi kestabilan dan kekokohan tanggapan tegangan sistem eksitasi tanpa metoda penempatan kutub. [7] membahas perilaku tegangan sistem eksitasi generator dengan metoda penempatan kutub dalam domain waktu. Informasi yang diperoleh bahwasanya performansi perilaku tegangan sistem eksitasi generator dengan metoda penempatan kutub lebih baik dibandingkan dengan performansi perilaku tegangan sistem eksitasi generator tanpa metoda penempatan kutub dan stabilizer. [8], pada jurnal ini membahas tentang analisa tanggapan tegangan sistem eksitasi generator dengan metoda $\mathrm{H}$. Informasi yang diperoleh bahwa tanggapan tegangan sistem eksitasi mempuyai performansi, kestabilan dan kekokohan yang lebih baik dibandingkan dengan sistem eksitasi tanpa metoda H . [9], jurnal ini membahas perencanaan optimal sistem kendali Automatic Voltage Regulator (AVR) untuk memperbaiki kestabilan tegangan dengan menggunakan algoritma genetika. [10], pembahasan jurnal ini tentang implementasi kontroler PID pada Automatic Voltage Regulator (AVR) untuk pengaturan tegangan eksitasi generator sinkron 3 fasa. Berdasarkan hasil dari beberapa penelitian yang sudah dilakukan terlihat bahwa analisa performansi tanggapan tegangan sistem eksitasi generator terhadap perubahan parameter belum dilakukan. Untuk itu dengan menggunakan bantuan perangkat lunak Matlab dilakukan analisa performansi tanggapan tegangan sistem eksitasi generator terhadap perubahan parameter.

Hasil dari penelitian ini diharapkan nantinya diperoleh informasi performansi dalam domain waktu dan performansi domain frekuensi dari sistem eksitasi generator terhadap perubahan parameter. Agar tercapai hasil penelitian yang efektif dan efisien maka penelitian ini dibatasi sebagai berikut:

1. Model sistem eksitasi generator bersifat linier, tak berubah terhadap waktu dan kontinu

2. Sistem eksitasi generator bersifat satu masukan satu keluaran 
Analisa dilakukan dengan bantuan perangkat lunak Matlab.

\section{TINJAUAN PUSTAKA}

Pada bagian ini membahas tentang pemodelan matematis komponen - komponen sistem eksitasi generator yang meliputi model amplifier, model eksiter dan model generator. Untuk model amplifier dinyatakan dalam bentuk persamaan (1) berikut [11]

$$
\frac{\mathrm{V}_{\mathrm{R}}(\mathrm{s})}{\mathrm{V}_{\mathrm{E}}(\mathrm{s})}=\frac{\mathrm{K}_{\mathrm{A}}}{1+\tau_{\mathrm{A}} \mathrm{s}}
$$

Nilai konstanta penguatan dari amplifier memiliki rentang nilai dari 10.0000 sampai 400.000 sedangkan nilai konstanta waktu amplifier memiliki rentang nilai dari 0.0200 detik sampai 0.1000 detik. Untuk model eksiter dinyatakan dalam bentuk persamaan (2) berikut [11]

$$
\frac{\mathrm{V}_{\mathrm{F}}(\mathrm{s})}{\mathrm{V}_{\mathrm{R}}(\mathrm{s})}=\frac{\mathrm{K}_{\mathrm{E}}}{1+\tau_{\mathrm{E}} \mathrm{s}}
$$

Untuk konstanta penguatan eksiter dan konstanta waktu eksiter ini mempuyai nilai yang kecil. Untuk model generator dinyatakan dalam bentuk persamaan (3) berikut [11]

$$
\frac{\mathrm{V}_{\mathrm{T}}(\mathrm{s})}{\mathrm{V}_{\mathrm{F}}(\mathrm{s})}=\frac{\mathrm{K}_{\mathrm{G}}}{1+\tau_{\mathrm{G}} \mathrm{s}}
$$

dimana nilai konstanta penguatan generator memiliki rentang nilai dari 0.7000 sampai 1.0000 sedangkan untuk konstanta waktu generator memiliki rentang nilai dari 1.0000 detik sampai 2.0000 detik pada keadaan beban nol sampai keadaan beban penuh. Komponen komponen sistem eksitasi generator ini kemudian digabungkan dan terbentuk diagram blok dari sistem eksitasi generator yang diperlihatkan pada Gambar 1. Berdasarkan diagram blok pada Gambar 1. kemudian diperoleh fungsi alih lingkar terbuka dan fungsi alih lingkar tertutup dari sistem eksitasi generator. Untuk fungsi alih lingkar terbuka diperlihatkan pada persamaan (4) dan fungsi alih lingkar tertutup diperlihatkan pada persamaan (5).

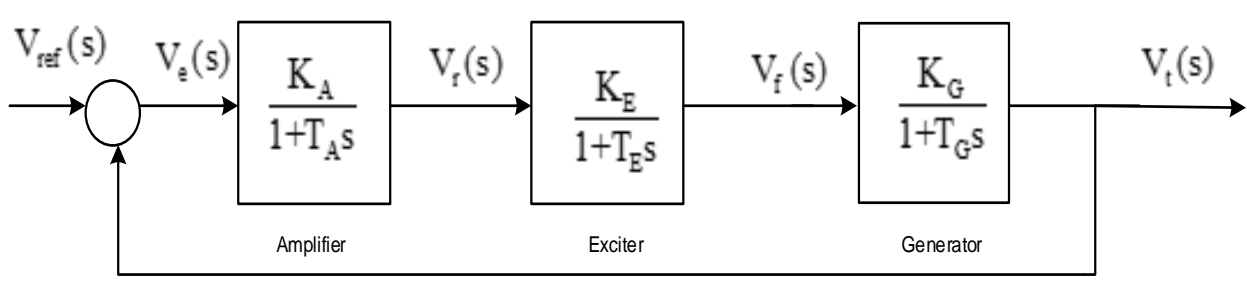

Gambar 1. Diagram Blok Sistem Eksitasi Generator Tipe Arus Searah [2]

Untuk fungsi alih lingkar terbuka dinyatakan dengan persamaan (4) berikut:

$$
\frac{V_{t}(s)}{V_{\text {ref }}(s)}=\frac{K_{A} K_{E} K_{G}}{\left(1+T_{A} s\right)\left(1+T_{E} s\right)\left(1+T_{G} s\right)}
$$

Untuk fungsi alih lingkar tertutup dinyatakan dengan persamaan (5) berikut:

$$
\frac{V_{t}(s)}{V_{\text {ref }}(s)}=\frac{K_{A} K_{E} K_{G}}{\left(1+T_{A} s\right)\left(1+T_{E} s\right)\left(1+T_{G} s\right)+K_{A} K_{E} K_{G}}
$$

Dengan mensubstitusi nilai - nilai pada Tabel 1. ke persamaan (4) dan (5) maka diperoleh persamaan (6) dan (7) berikut: 


$$
\begin{aligned}
& \frac{\mathrm{V}_{\mathrm{t}}(\mathrm{s})}{\mathrm{V}_{\text {ref }}(\mathrm{s})}=\frac{16.0000}{0.0180 \mathrm{~s}^{3}+0.4020 \mathrm{~s}^{2}+1.7600 \mathrm{~s}+1.0000} \\
& \frac{\mathrm{V}_{\mathrm{t}}(\mathrm{s})}{\mathrm{V}_{\text {ref }}(\mathrm{s})}=\frac{16.0000}{0.0180 \mathrm{~s}^{3}+0.4020 \mathrm{~s}^{2}+1.7600 \mathrm{~s}+17.0000}
\end{aligned}
$$

Dimana :

$\mathrm{K}_{\mathrm{A}}$ adalah konstanta penguatan amplifier

$\mathrm{T}_{\mathrm{A}}$ adalah konstanta waktu amplifier

$\mathrm{K}_{\mathrm{G}}$ adalah konstanta penguatan generator

$\mathrm{T}_{\mathrm{G}}$ adalah konstanta waktu generator

$\mathrm{K}_{\mathrm{E}}$ adalah konstanta penguatan exciter

$\mathrm{T}_{\mathrm{E}}$ adalah konstanta waktu exciter

\section{METODE PENELITIAN}

Pada bagian ini terdiri dari metodologi penelitian dan data - data parameter sistem eksitasi generator

\section{a. Metodologi Penelitian}

Penelitian ini dimulai dengan pemodelan matematis sistem eksitasi generator.Pemodelan matematis sistem eksitasi generator yang dibahas meliputi pemodelan amplifier, pemodelan eksiter dan pemodelan generator. Tipe sistem eksitasi generator yang digunakan adalah sistem eksitasi generator tipe arus searah dengan umpan balik satu dengan bentuk diagram blok yang diperlihatkan pada Gambar 1. Selain itu pemodelan matematis sistem eksitasi generator ini dilakukan dengan menggunakan persamaan linear diferensial dan transformasi Laplace.

Hasil pemodelan masing - masing komponen ini berupa fungsi alih orde satu. Fungsi alih dari masing-masing komponen ini kemudian digabungkan dan diperoleh fungsi alih lingkar terbuka dan fungsi alih lingkar tertutup dari sistem eksitasi generator. Untuk fungsi alih lingkar terbuka diperlihatkan pada persamaan (4) dan untuk fungsi alih lingkar tertutup diperlihatkan pada persamaan (5). Adapun keluaran dari kedua fungsi alih tersebut adalah tegangan terminal sedangkan masukannya adalah tegangan referensi. Nilai nilai parameter dari sistem eksitasi generator pada Tabel 1. Kemudian disubstitusikan ke persamaan (4) dan (5) serta diperoleh persamaan (6) dan (7).

Selanjutnya dilakukan analisa performansi tanggapan tegangan sistem eksitasi generator dalam domain waktu. Untuk analisa performansi dalam domain waktu ini meliputi analisa kesalahan dan analisa peralihan. Untuk analisa kesalahan, dengan menggunakan persamaan (4) dilakukan analisa kesalahan tanggapan tegangan sistem eksitasi generator untuk perubahan nilai konstanta penguatan amplifier. Analisa yang sama dilakukan untuk perubahan nilai konstanta waktu amplifier, perubahan nilai konstanta penguatan generator dan perubahan nilai konstanta waktu generator. Nilai batas bawah dan nilai batas atas untuk masing - masing konstanta diperlihatkan pada Tabel 2. Adapun parameter yang diamati dalam analisa kesalahan ini adalah konstanta kesalahan posisi, konstanta kesalahan keadaan mantap terhadap masukan undak satuan. Parameter - parameter tersebut diperoleh dari tanggapan tegangan sistem eksitasi generator dalam keadaan mantap. Secara lengkapnya analisa kesalahan bisa dilihat pada [12]

Untuk analisa peralihan, dengan menggunakan persamaan (5) dilakukan analisa peralihan tanggapan tegangan sistem eksitasi generator untuk perubahan nilai konstanta penguatan amplifier. Analisa yang sama dilakukan untuk perubahan nilai konstanta waktu amplifier, perubahan nilai konstanta penguatan generator dan perubahan nilai konstanta waktu generator. Adapun parameter yang diamati dalam analisa peralihan ini adalah waktu naik, waktu puncak, waktu keadaan mantap, lewatan maksimum dan nilai puncak. Parameter - parameter tersebut diperoleh dari tanggapan tegangan sistem eksitasi generator dalam keadaan peralihan. Secara lengkapnya analisa peralihan bisa dilihat pada [13]

Selanjutnya dilakukan analisa performansi tanggapan tegangan sistem eksitasi generator dalam domain frekuensi. Untuk analisa performansi dalam domain frekuensi ini 
meliputi analisa performansi lingkar terbuka dan analisa performansi lingkar tertutup. Untuk analisa performansi lingkar terbuka, dengan menggunakan persamaan (4) dilakukan analisa performansi lingkar terbuka tanggapan tegangan sistem eksitasi generator dalam domain frekuensi untuk perubahan nilai konstanta penguatan amplifier. Analisa yang sama dilakukan untuk perubahan nilai konstanta waktu amplifier, perubahan nilai konstanta penguatan generator dan perubahan nilai konstanta waktu generator. Adapun parameter yang diamati dalam analisa performansi lingkar terbuka ini adalah margin penguatan, frekuensi margin penguatan, margin fasa dan frekuensi margin fasa. Parameter - parameter tersebut diperoleh dari tanggapan tegangan sistem eksitasi generator terhadap masukan sinusoidal dalam bentuk diagram Bode. Secara lengkapnya analisa performansi lingkar terbuka dalam domain frekuensi bisa dilihat pada [14].

Untuk analisa performansi lingkar tertutup, dengan menggunakan persamaan (5) dilakukan analisa performansi lingkar tertutup tanggapan tegangan sistem eksitasi generator dalam domain frekuensi untuk perubahan nilai konstanta penguatan amplifier. Analisa yang sama dilakukan untuk perubahan nilai konstanta waktu amplifier, perubahan nilai konstanta penguatan generator dan perubahan nilai konstanta waktu generator. Adapun parameter yang diamati dalam analisa performansi lingkar tertutup ini meliputi lebar pita, nilai puncak resonansi dan frekuensi puncak resonansi. Parameter - parameter tersebut diperoleh dari tanggapan tegangan sistem eksitasi generator terhadap masukan sinusoidal dalam bentuk diagram Magnitude Bode. Hasil dari analisa performansi dalam domain waktu dan frekuensi ini diperolehnya informasi kepekaaan dari tanggapan tegangan sistem eksitasi generator terhadap perubahan parameter - parameter tersebut. Secara lengkapnya analisa performansi lingkar tertutup dalam domain frekuensi bisa dilihat pada [15],[16]

\section{b. Data - Data Parameter Sistem Eksitasi Generator}

Adapun parameter-parameter sistem eksitasi generator yang digunakan dalam penelitian ini diperlihatkan pada Tabel 1 . berikut [11]
Tabel 1. Nilai Parameter Sistem Eksitasi Generator

\begin{tabular}{|c|c|}
\hline Parameter & Nilai \\
\hline $\mathrm{K}_{\mathrm{A}}$ & 20.0000 \\
\hline $\mathrm{T}_{\mathrm{A}}$ & 0.0600 \\
\hline $\mathrm{K}_{\mathrm{E}}$ & 1.0000 \\
\hline $\mathrm{T}_{\mathrm{E}}$ & 0.2000 \\
\hline $\mathrm{K}_{\mathrm{G}}$ & 0.8000 \\
\hline $\mathrm{T}_{\mathrm{G}}$ & 1.5000 \\
\hline
\end{tabular}

Nilai batas bawah dan nilai batas atas untuk setiap konstanta parameter sistem eksitasi generator diperlihatkan pada Tabel 2. berikut [11]

Tabel 2. Rentang Nilai Parameter Sistem Eksitasi Generator

\begin{tabular}{|c|c|c|}
\hline Parameter & Maksimum & Minimum \\
\hline $\mathrm{K}_{\mathrm{A}}$ & 10.0000 & 40.0000 \\
\hline $\mathrm{T}_{\mathrm{A}}$ & 0.0200 & 0.1000 \\
\hline $\mathrm{K}_{\mathrm{G}}$ & 0.7000 & 1.0000 \\
\hline $\mathrm{T}_{\mathrm{G}}$ & 1.0000 & 2.0000 \\
\hline
\end{tabular}

\section{HASIL PEMBAHASAN}

Pada bagian ini dilakukan analisa performansi tanggapan tegangan sistem eksitasi generator terhadap perubahan parameter. Analisa performansi yang dilakukan meliputi analisa performansi dalam domain waktu dan analisa performansi dalam domain frekuensi. Untuk analisa performansi dalam domain waktu terdiri dari analisa kesalahan dan analisa peralihan dan untuk analisa performansi dalam domain frekuensi terdiri dari analisa performansi lingkar terbuka dan analisa performansi lingkar tertutup. Untuk perubahan parameter sistem eksitasi generator yang diamati meliputi perubahan konstanta penguatan amplifier, perubahan konstanta waktu amplifier, perubahan konstanta penguatan generator dan perubahan konstanta waktu generator.

Analisa kesalahan dari tanggapan tegangan sistem eksitasi generator ini ditunjukkan oleh nilai konstanta kesalahan posisi dan nilai kesalahan keadaan mantap terhadap masukan undak satuan. Kedua nilai tersebut diperoleh dari tanggapan tegangan sistem eksitasi 
generator dalam keadaaan mantap. Untuk analisa kesalahan dengan perubahan nilai konstanta penguatan amplifier diperoleh informasi bahwa tanggapan tegangan sistem eksitasi generator mempuyai batasan konstanta penguatan amplifier antara $10.0000 \mathrm{~s} / \mathrm{d}$ 45.0000. Untuk nilai konstanta penguatan amplifier diluar batas tersebut diperoleh kesalahan tanggapan tegangan sistem eksitasi generator yang semakin besar. Selain itu juga diperoleh informasi bahwa semakin besar nilai konstanta penguatan amplifier maka nilai konstanta kesalahan posisi akan semakin besar dan nilai kesalahan keadaan mantap untuk masukan undak satuan akan semakin kecil.

Untuk analisa kesalahan dengan perubahan konstanta waktu amplifier. Dengan melakukan simulasi diperoleh informasi nilai kesalahan tanggapan tegangan sistem eksitasi generator untuk setiap perubahan konstanta waktu amplifier. Hasil simulasi dengan menggunakan Matlab diperoleh informasi bahwa nilai konstanta waktu amplifier yang bisa digunakan berkisar antara $0.0200 \mathrm{~s} / \mathrm{d} \quad 0.1000$. Untuk rentang nilai konstanta waktu amplifier tersebut dimana tidak terjadi perubahan nilai konstanta kesalahan posisi dan nilai kesalahan keadaan mantap untuk masukan undak satuan. Dengan kata lain perubahan nilai konstanta waktu amplifier tidak mempengaruhi nilai kesalahan dari tanggapan tegangan sistem eksitasi generator.

Untuk analisa kesalahan dengan perubahan konstanta penguatan generator dimana diperoleh informasi nilai kesalahan dari tanggapan tegangan sistem eksitasi generator, dimana nilai konstanta kesalahan posisi dari tanggapan tegangan sistem eksitasi generator akan bertambah besar seiring dengan bertambah besarnya nilai konstanta penguatan generator. Dengan semakin bertambah besarnya nilai konstanta kesalahan posisi ini mengakibatkan nilai kesalahan keadaan mantap untuk masukan undak satuan dari tanggapan tegangan sistem eksitasi generator akan semakin kecil. Adapun perubahan nilai konstanta penguatan generator ini berkisar antara $0.7000 \mathrm{~s} / \mathrm{d} 1.0000$.

Untuk analisa kesalahan dengan perubahan konstanta waktu generator. Dengan melakukan simulasi diperoleh informasi nilai kesalahan tanggapan tegangan sistem eksitasi generator untuk setiap perubahan konstanta waktu generator. Hasil simulasi dengan menggunakan
Matlab diperoleh informasi bahwa nilai konstanta waktu generator yang bisa digunakan berkisar antara $1.0000 \mathrm{~s} / \mathrm{d} 2.0000$. Untuk rentang nilai konstanta waktu generator tersebut dimana tidak terjadi perubahan nilai konstanta kesalahan posisi dan nilai kesalahan keadaan mantap untuk masukan undak satuan. Dengan kata lain perubahan nilai konstanta waktu generator tidak mempengaruhi nilai kesalahan dari tanggapan tegangan sistem eksitasi generator.

Analisa peralihan dari tanggapan tegangan sistem eksitasi generator ini ditunjukkan oleh parameter waktu naik, waktu puncak, waktu keadaan mantap, lewatan maksimum dan nilai puncak. Parameter - parameter tersebut diperoleh dari tanggapan tegangan sistem eksitasi generator dalam keadaan peralihan. Untuk analisa peralihan dari tanggapan tegangan sistem eksitasi generator dengan perubahan konstanta penguatan amplifier diperlihatkan pada Gambar 2. berikut

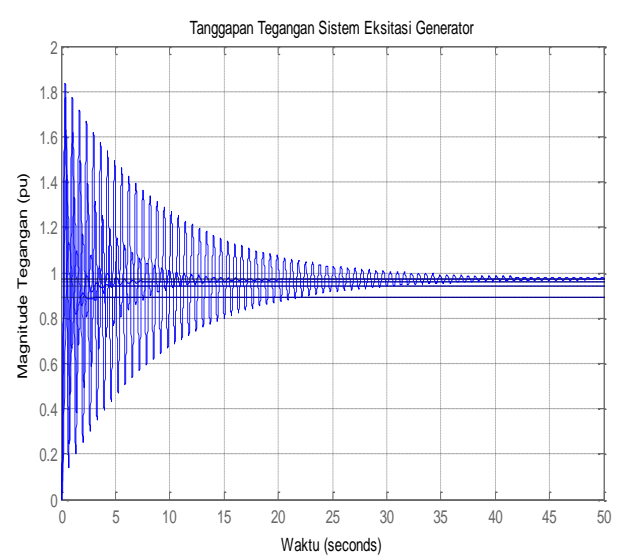

Gambar 2. Tanggapan Peralihan Untuk Perubahan Konstanta Penguatan Amplifier

Berdasarkan Gambar 3. diperoleh informasi bahwa semakin besar nilai konstanta penguatan amplifier maka waktu naik dan waktu puncak semakin kecil sedangkan waktu keadaan mantap, lewatan maksimum dan nilai puncak dari tanggapan tegangan sistem eksitasi akan semakin besar.

Untuk analisa peralihan dari tanggapan tegangan dengan perubahan nilai konstanta waktu amplifier diperoleh informasi bahwa tanggapan tegangan sistem eksitasi generator mempuyai batasan konstanta waktu amplifier 
antara $0.0200 \mathrm{~s} / \mathrm{d} 0.1000$ dan diluar batas tersebut tanggapan tegangan sistem eksitasi generator akan mempuyai tanggapan peralihan yang tidak memuaskan. Adapun tanggapan peralihan dari tanggapan tegangan sistem eksitasi generator untuk perubahan konstanta waktu amplifier diperlihatkan pada Gambar 3. berikut

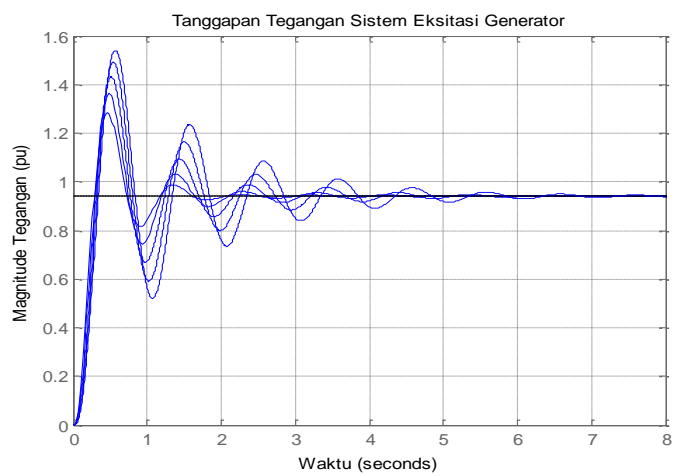

Gambar 3. Tanggapan Peralihan Untuk Perubahan Konstanta Waktu Amplifier

Berdasarkan Gambar 3. diperoleh informasi bahwa semakin besar nilai konstanta waktu amplifier maka waktu naik, waktu puncak, waktu keadaan mantap, lewatan maksimum dan nilai puncak dari tanggapan tegangan sistem eksitasi generator akan semakin besar.

Untuk analisa peralihan dari tanggapan tegangan dengan perubahan nilai konstanta penguatan generator diperoleh informasi bahwa tanggapan tegangan sistem eksitasi generator mempuyai batasan konstanta penguatan generator antara $0.7000 \mathrm{~s} / \mathrm{d} 1.0000$ dan diluar batas tersebut tanggapan tegangan sistem eksitasi generator akan mempuyai tanggapan peralihan yang tidak memuaskan. Adapun tanggapan peralihan dari tanggapan tegangan sistem eksitasi generator untuk perubahan konstanta penguatan generator diperlihatkan pada Gambar 4. berikut

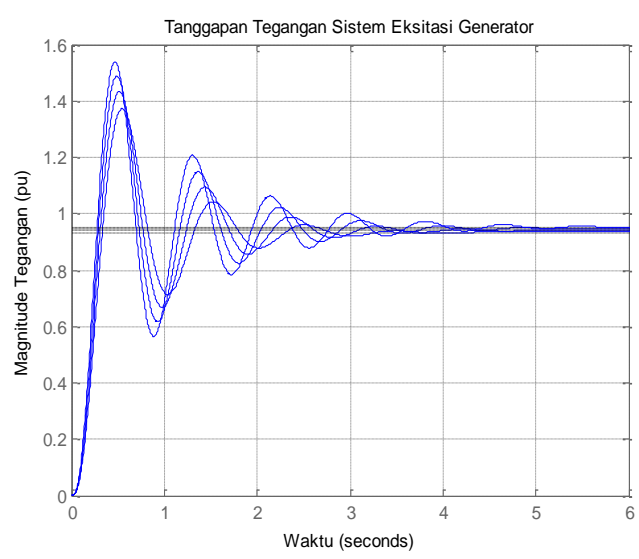

Gambar 4. Tanggapan Peralihan Untuk Perubahan Konstanta Penguatan Generator

Berdasarkan Gambar 4. diperoleh informasi bahwa semakin besar nilai konstanta penguatan generator maka waktu naik dan waktu puncak akan semakin kecil sedangkan waktu keadaan mantap, lewatan maksimum dan nilai puncak akan semakin besar.

Untuk analisa peralihan dari tanggapan tegangan dengan perubahan nilai konstanta waktu generator diperoleh informasi bahwa tanggapan tegangan sistem eksitasi generator mempuyai batasan konstanta penguatan generator antara $1.0000 \mathrm{~s} / \mathrm{d} 2.0000$ dan diluar batas tersebut tanggapan tegangan sistem eksitasi generator akan mempuyai tanggapan peralihan yang tidak memuaskan. Adapun tanggapan peralihan dari tanggapan tegangan sistem eksitasi generator untuk perubahan konstanta waktu generator diperlihatkan pada Gambar 5. berikut

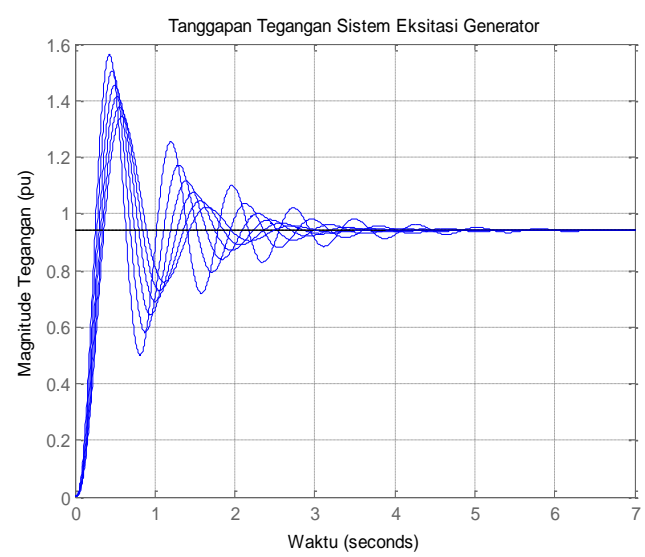

Gambar 5. Tanggapan Peralihan Untuk Perubahan Konstanta Waktu Generator 
Berdasarkan Gambar 5. diperoleh informasi bahwa semakin besar nilai konstanta waktu generator maka waktu naik, waktu puncak akan semakin besar sedangkan waktu keadaan mantap, lewatan maksimum dan nilai puncak akan semakin kecil.

Untuk analisa performansi lingkar terbuka dalam domain frekuensi ditunjukkan oleh nilai margin penguatan, nilai frekuensi margin penguatan, nilai margin fasa dan nilai frekuensi margin fasa. Nilai - nilai tersebut diperoleh dari tanggapan tegangan sistem eksitasi generator terhadap masukan sinusoidal. Untuk analisa performansi lingkar terbuka dalam domain frekuensi dari tanggapan tegangan sistem eksitasi generator dengan perubahan konstanta penguatan amplifier diperlihatkan dengan diagram Bode pada Gambar 6. berikut

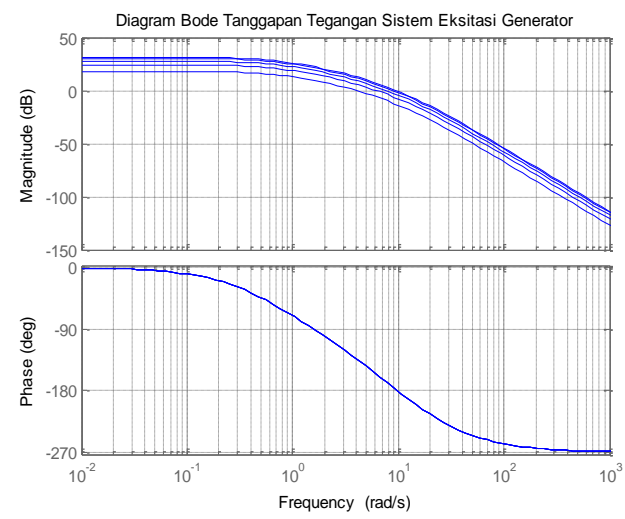

Gambar 6. Diagram Bode Untuk Perubahan Konstanta Penguatan Amplifier

Berdasarkan Gambar 6. terlihat bahwa nilai margin penguatan, nilai frekuensi margin penguatan, nilai margin fasa dan nilai frekuensi margin fasa tanggapan tegangan sistem eksitasi generator mengalami penurunan seiring dengan kenaikan konstanta penguatan amplifier dari sistem eksitasi generator. Adapun perubahan nilai konstanta penguatan amplifier yang digunakan berkisar antara $10.0000 \mathrm{~s} / \mathrm{d} 45.0000$.

Untuk analisa performansi lingkar terbuka dalam domain frekuensi dari tanggapan tegangan sistem eksitasi generator dengan perubahan konstanta waktu amplifier diperlihatkan dengan diagram Bode pada Gambar 7. berikut

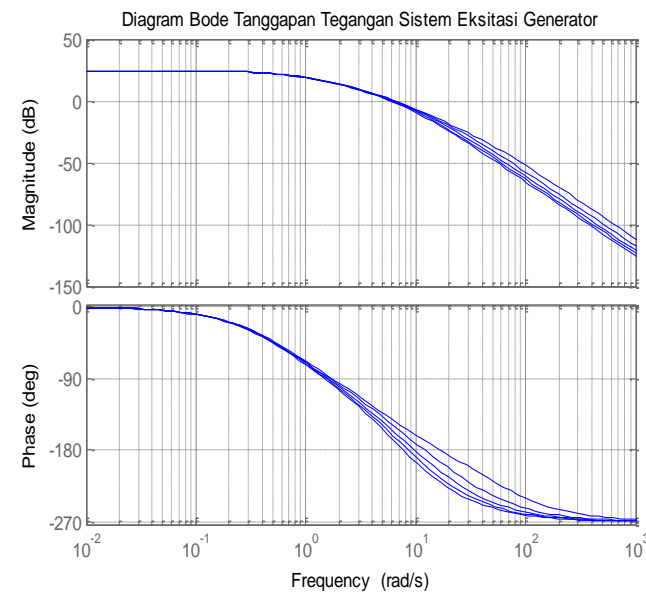

Gambar 7. Diagram Bode Untuk Perubahan Konstanta Waktu Amplifier

Berdasarkan Gambar 7. terlihat bahwa nilai margin penguatan, nilai frekuensi margin penguatan, nilai margin fasa dan nilai frekuensi margin fasa dari tanggapan sistem eksitasi generator mengalami penurunan seiring dengan kenaikan konstanta waktu amplifier dari sistem eksitasi generator. Adapun perubahan nilai konstanta waktu amplifier ini berkisar antara $0.0200 \mathrm{~s} / \mathrm{d} 0.1000$.

Untuk analisa performansi lingkar terbuka dalam domain frekuensi dari tanggapan tegangan sistem eksitasi generator dengan perubahan konstanta penguatan generator diperlihatkan dengan diagram Bode pada Gambar 8. berikut

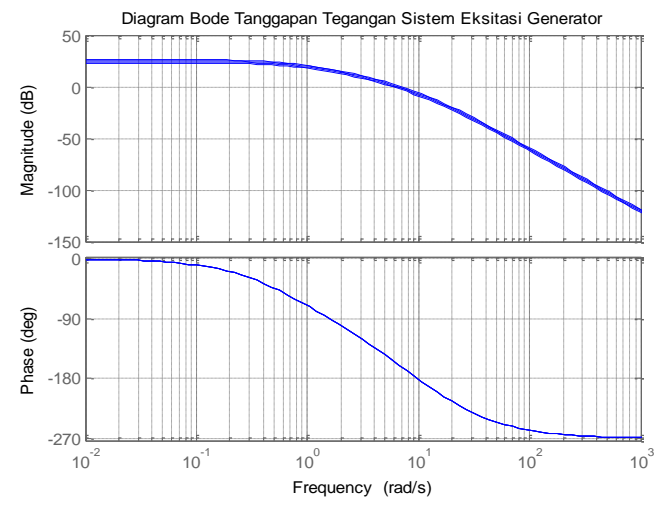

Gambar 8. Diagram Bode Untuk Perubahan Konstanta Penguatan Generator

Berdasarkan Gambar 8. terlihat bahwa nilai margin penguatan dan nilai margin fasa 
dari tanggapan tegangan sistem eksitasi generator mengalami penurunan seiring dengan kenaikan nilai konstanta penguatan generator sedangkan nilai frekuensi margin penguatan tidak mengalami perubahan dan nilai frekuensi margin fasa mengalami kenaikan. Perubahan nilai konstanta penguatan generator ini berkisar antara $0.7000 \mathrm{~s} / \mathrm{d} 1.0000$.

Untuk analisa performansi lingkar terbuka dalam domain frekuensi dari tanggapan tegangan sistem eksitasi generator dengan perubahan konstanta waktu generator diperlihatkan dengan diagram Bode pada Gambar 9. berikut

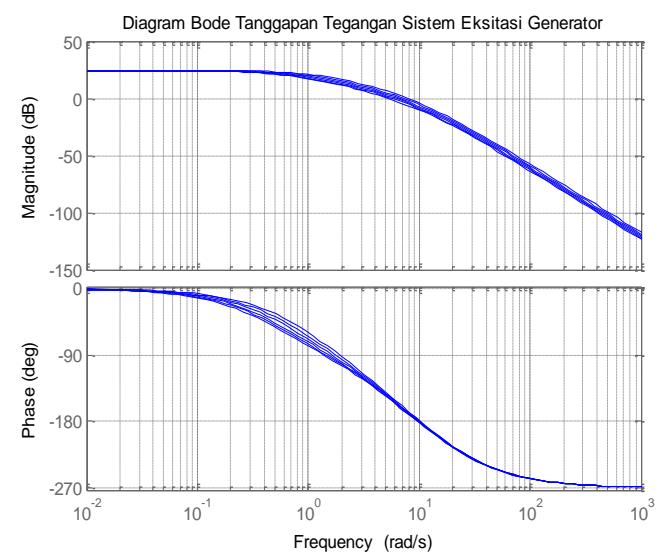

Gambar 9. Diagram Bode Untuk Perubahan Konstanta Waktu Generator

Berdasarkan Gambar 9. terlihat bahwa nilai margin penguatan dan margin fasa dari tanggapan tegangan sistem eksitasi generator mengalami kenaikan seiring dengan kenaikan nilai konstanta waktu generator sedangkan nilai frekuensi margin penguatan dan nilai frekuensi margin fasa mengalami penurunan. Perubahan nilai konstanta waktu generator ini berkisar antara $1.0000 \mathrm{~s} / \mathrm{d} 2.0000$.

Untuk analisa performansi lingkar tertutup dalam domain frekuensi ditunjukkan oleh nilai lebar pita, nilai puncak resonansi dan frekuensi puncak resonansi. Nilai - nilai tersebut diperoleh dari tanggapan tegangan sistem eksitasi generator terhadap masukan sinusoidal. Untuk analisa performansi lingkar tertutup dalam domain frekuensi dari tanggapan tegangan sistem eksitasi generator dengan perubahan konstanta penguatan amplifier diperlihatkan dengan diagram Magnitude Bode pada Gambar 10. Berikut

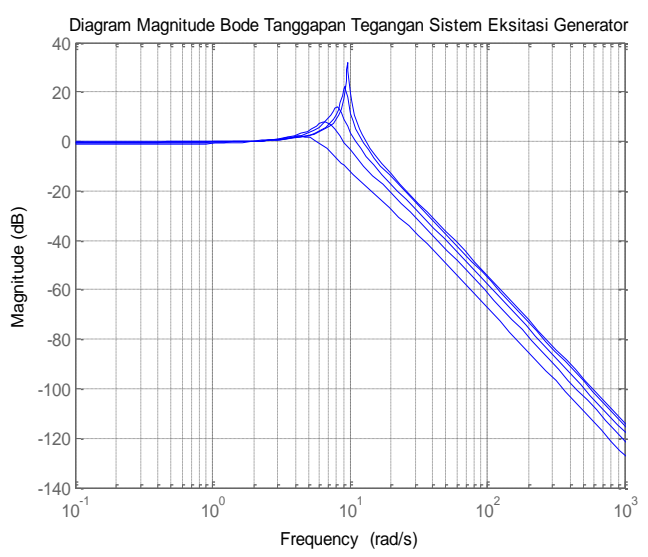

Gambar 10. Diagram Magnitude Bode Sistem Eksitasi Generator Untuk Perubahan Konstanta Penguatan Amplifier

Berdasarkan Gambar 10. terlihat bahwa nilai lebar pita, nilai puncak resonansi dan frekuensi puncak resonansi dari tanggapan tegangan sistem eksitasi generator bertambah besar seiring dengan kenaikan konstanta penguatan amplifier dari sistem eksitasi generator. Adapun perubahan nilai konstanta penguatan amplifier ini berkisar antara 10.0000 s/d 45.0000

Untuk analisa performansi lingkar tertutup dalam domain frekuensi dari tanggapan tegangan sistem eksitasi generator dengan perubahan konstanta waktu amplifier diperlihatkan dengan diagram Magnitude Bode pada Gambar 11. berikut

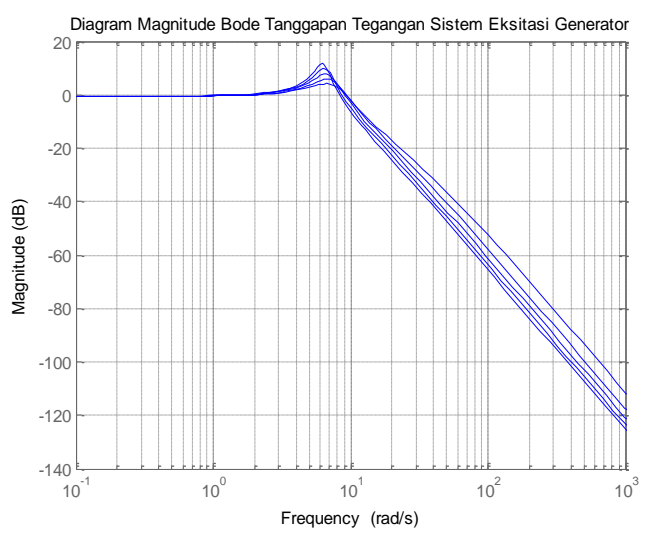

Gambar 11. Diagram Magnitude Bode Sistem Eksitasi Generator Untuk Perubahan Konstanta Waktu Amplifier 
Berdasarkan Gambar 11. terlihat bahwa nilai lebar pita dari tanggapan sistem eksitasi generator bertambah kecil dan nilai puncak resonansi dari tanggapan sistem eksitasi generator bertambah besar seiring dengan kenaikan konstanta waktu amplifier dari sistem eksitasi generator. Untuk nilai frekuensi puncak resonansi dari tanggapan tegangan sistem eksitasi generator bertambah besar untuk nilai konstanta waktu amplifier antara $0.0200 \mathrm{~s} / \mathrm{d}$ 0.0400 dan nilai frekuensi puncak resonansi dari tanggapan tegangan sistem eksitasi generator bertambah kecil untuk nilai konstanta waktu amplifier antara $0.0400 \mathrm{~s} / \mathrm{d} 0.1000$

Untuk analisa performansi lingkar tertutup dalam domain frekuensi dari tanggapan tegangan sistem eksitasi generator dengan perubahan konstanta penguatan generator diperlihatkan dengan diagram Magnitude Bode pada Gambar 12. berikut

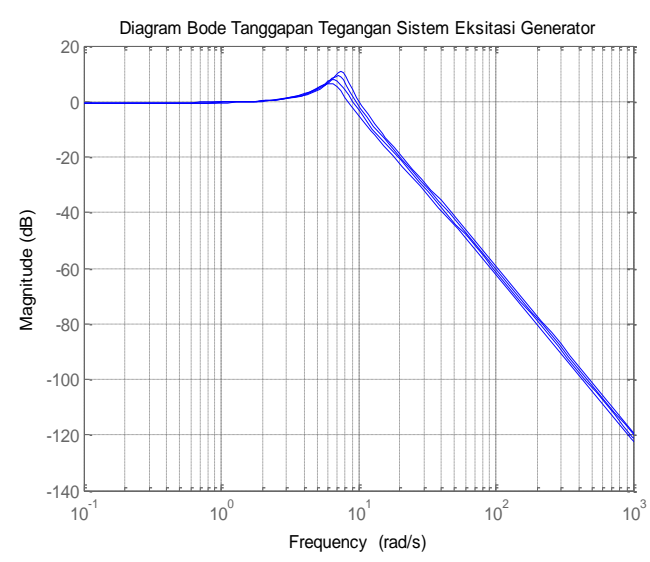

Gambar 2. Diagram Magnitude Bode Sistem Eksitasi Generator Untuk Perubahan Konstanta Penguatan Generator

Berdasarkan Gambar 12. terlihat bahwa nilai lebar pita, nilai puncak resonansi dan frekuensi puncak resonansi dari tanggapan tegangan sistem eksitasi generator bertambah besar seiring dengan kenaikan konstanta penguatan generator dari sistem eksitasi generator. Adapun perubahan nilai konstanta penguatan generator ini berkisar antara 0.7000 s/d 1.0000

Untuk analisa performansi lingkar tertutup dalam domain frekuensi dari tanggapan tegangan sistem eksitasi generator dengan perubahan konstanta waktu generator diperlihatkan dengan diagram Magnitude Bode pada Gambar 13. berikut

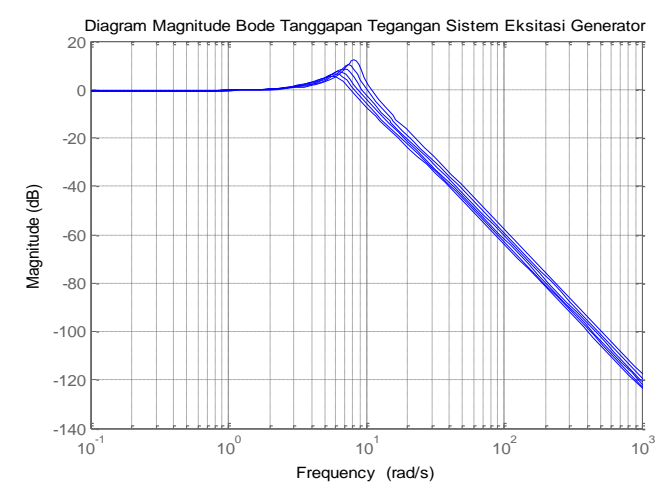

Gambar 13. Diagram Magnitude Bode Sistem Eksitasi Generator Untuk Perubahan Konstanta Waktu Generator

Berdasarkan Gambar 13. terlihat bahwa nilai lebar pita, nilai puncak resonansi dan frekuensi puncak resonansi dari tanggapan tegangan sistem eksitasi generator bertambah kecil seiring dengan kenaikan konstanta waktu generator dari sistem eksitasi generator. Adapun perubahan nilai konstanta penguatan generator ini berkisar antara $1.0000 \mathrm{~s} / \mathrm{d} 2.0000$

\section{KESIMPULAN}

Kesimpulan dari penelitian ini adalah bahwa performansi tanggapan tegangan sistem eksitasi generator dalam domain waktu dan domain frekuensi sangat peka terhadap perubahan parameter terutama untuk perubahan konstanta penguatan amplifier, perubahan konstanta waktu amplifier, perubahan konstanta penguatan generator dan perubahan konstanta waktu generator. Adapun perubahan konstanta penguatan amplifier berkisar antara $10.0000 \mathrm{~s} / \mathrm{d} 45.0000$, perubahan konstanta waktu amplifier berkisar antara $0.0200 \mathrm{~s} / \mathrm{d}$ 0.1000 , perubahan konstanta penguatan generator berkisar antara $0.7000 \mathrm{~s} / \mathrm{d} 1.0000$ dan perubahan konstanta waktu generator berkisar antara $1.0000 \mathrm{~s} / \mathrm{d} 2.0000$. 


\section{DAFTAR PUSTAKA}

[1] Laksono, H. D., Revan , M. \& Rabiarahim, A., 2014. Pemodelan dan Analisa Sistem Eksitasi Generator. Teknika , 21(01).

[2] Laksono, H. D., 2014. Kendali Sistem Tenaga Listrik Dengan Matlab, Jogjakarta : Graha Ilmu .

[3] Eremia, M., \& Shahidehpour, M, 2013. Handbook of Electrical Power System Dynamics . New Jersey: Wiley.

[4] Laksono, H. D. \& Revan , M., 2014. Perancangan dan Analisa Kendali Sistem Eksitasi Generator Tipe Arus Searah Dengan PIDTool Model Paralel. Teknika, 21(3).

[5] Laksono, H. D. \& Yulianto , N. F., 2013. Evaluasi Pola Tingkah Laku Tegangan Sistem Eksitasi Generator Dengan Metoda Penempatan Kutub Menggunakan Algoritma Bass - Gura. Jurnal Nasional Teknik Elektro, 02(02).

[6] Laksono, H. D. \& Yulianto , N. F., 2013. Evaluasi Kestabilan dan Kekokohan Tanggapan Tegangan Sistem Eksitasi Generator Dengan Metoda Penempatan Kutub Menggunakan Algoritma Ackerman - Gura. Konferensi Nasional Ke - 7 Forum Pendidikan Tinggi Teknik Elektro Indonesia (FORTEI), Padang $26-28$ September 2013

[7] Laksono, H. D. \& Yulianto, N. F., 2013. Perilaku Tegangan Sistem Eksitasi Generator Dengan Metoda Penempatan Kutub Dalam Domain Waktu. Jurnal Nasional Teknik Elektro, 02(01).

[8] Laksono, H. D. \& Rezki, S. O., 2012. Penerapan Sistem Kendali Kokoh Dengan Metoda H Pada Sistem Eksitasi Generator. Amplifier, 02(02).

[9] Endriyanto NW, 2001, Perencanaan Optimal Sistem Kontrol AVR (Automatic Voltage Regulator) Untuk Memperbaiki Kestabilan Tegangan Dengan Menggunakan Algoritma Genetik, Fakultas Teknik, Universitas Diponegoro, Semarang.

[10] Amin Setiadji, 2000, Implementasi Implementasi Kontroler PID Pada AVR (Automatic Voltage Regulator) untuk Pengaturan Tegangan Eksitasi Generator Sinkron 3 Fasa, Politeknik Elektronika
Negeri Surabaya - Institute Teknologi Sepuluh November, Surabaya.

[11] Saadat, H., 1999. Power System Analysis. Canada: McGraw Hill.

[12] Ajit K Mandal , 2006. Introduction To Control Engineering. India : New Age International .

[13] Ogata, K., 1996. Teknik Kontrol Automatik. Jakarta : Penerbit Erlangga .

[14] Distefano, J. J., Stubberud, A. R. \& Williams, I. J., 1990. Feedback and Control Systems. New York : McGraw Hill

[15] Franklin, G. \& Naeini, A. E., 1986. Feedback. New York : Addison - Wesley.

[16] Laksono, H. D., 2014. Sistem Kendali. Jogjakarta: Graha Ilmu.

\section{Biodata Penulis}

Heru Dibyo Laksono ST, MT, Lahir di Sawah Lunto, 7 Januari 1977, Menamatkan S1 di Jurusan Teknik Elektro Universitas Andalas (Unand) Padang tahun 2000 bidang Teknik Tenaga Listrik. Pendidikan S2 bidang Kendali dan Sistem diselesaikan di Institute Teknologi Bandung (ITB) tahun 2004. Masuk sebagai dosen Teknik Elektro Universitas Andalas sejak tahun 2005.

Adri Febrianda, Lahir di Kabanjahe pada tanggal 08 Februari 1993. Terdaftar sebagai mahasiswa jurusan Teknik Elektro Fakultas Teknik Universitas Andalas pada tahun 2010 dengan bidang keahlian sistem tenaga listrik. 